\title{
CONSUMER BEHAVIOR IN THE ERA OF INDUSTRIAL REVOLUTION 4.0
}

\author{
Maheswari Kadek Indah*, Gorda Anak Agung Ngurah Oka Suryadinatha \\ Undiknas Graduate School, Bali, Indonesia \\ *E-mail: indah maheswari@yahoo.com
}

\begin{abstract}
The rapid development of digital technology has led us to the 4.0 industrial revolution. The growth of $Y$ generations (millennial generation) is a witness of life and birth, growth, and the development of technology. This causes changes in consumer behavior, especially in purchasing fashion products which are no longer as basic needs, but it has become an aesthetic value. The $Y$ Generations tend to enjoy the convenience offered by the online media to fulfill their lifestyle. Nowadays, business people or entrepreneurs are currently changing their way of selling and marketing their products from a conventional way to be more modern way in which one of the ways used online media. The formulation of the problem in this study is to know how the consumer behavior of the $\mathrm{Y}$ Generations in purchasing fashion products in the era of industrial revolution 4.0. The study is in Denpasar, Bali. Data were analyzed using descriptive qualitative analysis. The results of this study were obtained from respondents (the $Y$ generations consumers, business people and lecturers of marketing management) shows that the development of technology can change the consumer behavior of $Y$ generations: (1) the $Y$ generations will review the products before the purchase; (2) they are more consumptive than the previous generations; (3) environment can influence the consumer behavior of $Y$ generations and the online media give the easiest way that can be enjoyed by $\mathrm{Y}$ generations in purchasing fashion products.
\end{abstract}

\section{KEY WORDS}

Consumer behavior, marketing management, generation $\mathrm{Y}$, online shop.

Advances in digital technology bring us to the fourth wave of industrial revolution or Industrial Revolution 4.0, the latest trends in the world of such sophisticated technology. When advances in technology and the internet are developing on the other hand the growth of generation $Y$ also. Generation $Y$ has been attached to technology and the internet. The characteristics of generation $Y$ are using gadgets in their daily lives, so they need to optimize the use of technology and information in providing services to consumers of generation $Y$ (Suryadi, 2015). Generation $Y$ is known to be very close to technology. The life of this generation cannot be separated from technology and the internet. Generation $Y$ was born when mobile phones and social media emerged, so that this generation is more tech-savvy than previous generations. Y generation's literacy in technology will have an impact on everyday culture or lifestyle.

According to Mix Marcomm (2018: 31) the generation Y character, aside digital literacy, also has another characteristics that is more consumptive not only to fulfill needs, but to exchange functions into an activity to find satisfaction, channel hobbies, and only as a means of satisfying needs. This resulted in a change from consumer behavior at this time that is more consumptive behavior. Consumptive behavior is an act of using incomplete products, buying goods because of gifts and buying products because many people use these products (Oktafikasari, 2017: 685). Consumptive lifestyle whose orientation is directed towards pleasure, pleasure and satisfaction in consuming excessive goods. These conditions bring habits and lifestyle changes in a relatively short time leading to an increasingly luxurious and excessive direction so that it will later trigger consumer behavior in the community (Windayanti and Supriyadi, 2019: 1101).

The lifestyle and behavior of the $\mathrm{Y}$ generation of consumers has now changed, especially in terms of fulfilling fashion products. The development of fashion products has succeeded in changing consumer perceptions; the primary function of clothing is changing 
into a tool to express identity. Fashion is an indicator of a person's social status and is used as a means of self-actualization (Simaremare and Mujiasih, 2018: 163). Generation Y consumers who are increasingly concerned with appearance and adjust to the times, fashion products become a value both in terms of brand, style, fashionable and trend. Not surprisingly, fashion product businesses with online media are rife and rampant.

The high demand of the $Y$ generation of fashion products, businesses must develop capabilities and innovate to face competition to meet consumer needs and encourage consumers to continue to consume the products offered in an effort to improve competitiveness with other companies engaged in the same field (Abdi and Supriono, 2019). According to Mahardika and Sunariani (2019) the intense competition in local and global businesses, the need for competition to be the best is competitive advantage in order to be able to win the competition in today's era. Businesses must apply modern marketing concepts that are market-oriented or customer-oriented because they are the spearhead of marketing success. Technological developments cause marketers to be smart in utilizing technology and continue to innovate on marketing products and strategies, by changing traditional marketing techniques to digital (Sembiring \& Ananda, 2019: 360). One of them is in the era of the industrial revolution 4.0 today; there are so many online business choices that can be used. Consumers can choose various online media that they like using Instagram, Facebook, Shopee, Tokopedia, etc. Purchasing system using online media can provide convenience related to time efficiency, can reduce costs for the search process (search costs) that must be spent by consumers when they want to buy goods. Desired items can be easily obtained with many choices available without the need to feel difficult to obtain them. Based on this background, in this study, researchers will conduct research on consumer behavior in the 4.0 revolution era in the purchase of fashion products dominated by consumers from generation $Y$ along with the emergence of diversity of fashion products and the ease that can be enjoyed from online shopping.

\section{LITERATURE REVIEW}

Consumer behavior is centred on the way individuals make decisions to utilize their available resources (time, money and effort) to buy goods related to consumption. This includes what they buy, why they buy, when they buy, where they buy, how often they buy and how often they use the product (Schiffman and Kanuk, 2018: 6). Consumer behavior is the act of examining individuals, groups, and organizations to choose, use, service, ideas or experiences in order to satisfy their needs and desires (Asra and Suyanto, 2019). Factors that influence consumer behavior are cultural factors, personal factors (such as age, stage of purchase, economic conditions, and lifestyle), Psychological Factors (such as recognized needs, self-esteem or needs to be accepted in the environment).

According to Kartajaya (2017: 318) the concept of marketing must indeed evolve from product-driven marketing (Marketing 1.0), moving towards customer-centric marketing (Marekting 2.0), to human-centric marketing (Marketing 3.0) Today the business landscape is moving towards an economic era digital that creates a variety of conveniences that were never felt by previous generations. On the other hand, technology is a scourge for the public, namely cybercrime to hoax, which is a negative effect of technology that can be unsettling to the public. The marketing shift started from product-oriented marketing (1.0), to customeroriented marketing (2.0), to human-oriented marketing (3.0) and is now experiencing a shift to marketing 4.0 that helps marketers switch to the digital economy, which defines re key concept of marketing.

Millennial generation or commonly referred to as generation $Y$ is the generation born in 1980-2000 with criteria full of visionary ideas, innovative, utilizing technology and prioritizing work performance. According to Mix Marcomm (2018: 31) 10 millennial generation characters are digital literacy; consumptive; saving for something dreamed of; knowledgeable; digital as a communication media; being an entrepreneur without preparation, prioritizing facilities and appreciation in the world of work; rise of the experiential, or the more plunge into exciting and unique experiences, the more the millennial generation 
feels successful and can share these exciting moments on social media; radical transparency or millennial generation highly appreciates honest, authentic and unique content; Fear of Missing Out (FOMO). According Kartajaya (2017: 268) citizen 4.0 in the millennial is very concerned about the quality of life that is closely related to efforts to improve the welfare of himself and his family, but achieving the desired welfare certainly does not happen with him and in his journey millennials often compete with each other

According to Damaya (2018: 26) online shop is one way of selling by utilizing the internet. According to Mulianingsih, Fauzi and Alfisyah (2019) that an online shop without space and time is limited, this is what attracts consumers to do online shopping, because the purchasing process is faster, easier and can be done anywhere, so that the shopping process is more efficient.

Today's consumers are more dominated by $Y$ generation (millennial generation), a generation that is very close by technology and the internet. $Y$ Generation is growing when technology and the internet are developing at a rapid pace. The existence of technology and the internet has caused a change in consumer behavior. One of the developing consumer behaviors is that consumers are more consumptive, like buying in a practical way and prefer to be a follower and are influenced by the environment. Consumers prefer to use online media, technology, and the internet in purchasing goods, meeting their daily needs, or fulfilling their lifestyle. The reason is that by using online media consumers get the desired product instantly without having to require special time.

Along with the domination of $Y$ generation in Indonesia, especially in Denpasar, it has also led to changes in consumer behavior, especially in the fulfillment of fashion products. The development of fashion products has succeeded in changing consumers' perceptions of the primary function of clothing into a tool for expressing identity, creating prosperity from creativity and connecting global society (Soeaidy, Taufiq and Mandasari, 2018). Fulfillment of fashion products has now experienced convenience along with the increasing use of the internet and social media.

This research will be conducted to obtain information related to consumer behavior in $Y$ generation in purchasing fashion products in Revolution Era 4.0. Retrieval of data to obtain this information is done in three ways, namely observation, interviews and documentation will be carried out to obtain more accurate, clear and complete data. After conducting the interview, then the data will be examined with the aim that the data received is true.

\section{METHODS OF RESEARCH}

The research location in this study is in Denpasar, because the population of the largest regency / city and regency / city with the highest labor force is the City of Denpasar. The study was conducted using qualitative descriptive methods to answer the problem formulations in this study. The informants in this study were selected using purposive sampling technique, namely the technique of collecting data sources with certain considerations (Sugiyono, 2014: 218). The informants in this study are fashion product business owners who have applied a minimum of 2 years online business strategy located in Denpasar; generation $Y$ consumers with age criteria 24-30 years; have a minimum of 2 years of own income and single status; and marketing management lecturers as representatives of academics. After determining the sample criteria, the sample collection technique used is accidental sampling. Accidental sampling is a sampling technique based on accidental encounters at the time, namely consumers who incidentally or incidentally were found and according to criteria or considerations as informants so that they can be used as samples.

Source of data used are primary data and secondary data. Data collection techniques in this study are to make observations. The data analysis technique used is the analysis before in the field, data analysis in the field (data reduction, data presentation, and conclusions). Reducing data means summarizing and focusing on things that are important in accordance with the themes and issues in this study. The purpose of presenting data is to make it easier to understand what is happening based on what has been understood. The conclusions in this qualitative study are findings that are descriptive in nature. 


\section{RESULTS AND DISCUSSION}

A buying and selling process of a product will be very closely related to consumers. Consumers are important figures whose characters must be recognized. Another term is that the consumer is king; the king is the ruler which means that every response and request from the consumer must be responded to as much as possible with the reason that the continuity of the business is very dependent on the buyer, so of course it is necessary to know to recognize consumer behavior. Consumers must have their own reasons and standards for buying a product. Consumer behavior can be seen from how to find information about the product to be purchased, negotiating with businesses to get the desired product and price.

Consumer behavior according to Engel et al in Sangadji and Sopiah (2013: 7) is an action directly involved in the acquisition, consumption, and finishing of products / services, including the processes that precede and follow this action. As with any consumer behavior owned by consumers, businesses will continue to serve in order to make the purchase process that can satisfy consumers. Consumer behavior is different because there are things that influence it, one of which is technological progress. Millennial generation or commonly referred to as generation $Y$ is the generation born in 1980 to 2000 with criteria full of visionary ideas, innovative, utilizing technology and prioritizing work performance (Mix Marcom, 2018: 11). Millennial generation is a generation that is a witness born, lived, and developed with technological change. For example ranging from color TV, video games, Walkman, internet, cell phones and PlayStation. According to the results of research conducted by Sudarwinarti, 2019 that this generation is commonly called the internet generation, or the cool version is iGen. Based on this research found several characters from the millennial generation, namely trusting the content of individual testimonials rather than one-way information. They no longer trust certain advertisements, but they will instead find out in advance reviews or testimonials done by others from the internet, must have a social media account, a change in conventional reading interest because it will make it saturated, they tend to be interested in reading with attractive colors and images, and prefer gadgets or cell phones over television; and the family as a center of consideration in decision making.

Differences in consumer behavior can be seen from segmentation because the basic characteristics of consumer behavior become the basis for determining segmentation. The segmentation used is no longer focused on determining which markets to target, who are the consumers to be targeted, but with the existence of this technology it focuses instead on determining and classifying consumers from their life style and behavior. The existence of changes in life style (lifestyle) can also be influenced by the environment.

Consumer behavior is obtained based on the results of research and observations, interviews and documentation that there are differences in consumer behavior, especially for generation $\mathrm{Y}$, because most consumers who buy fashion products are consumers belonging to generation Y. I Wayan Aris Sugiantara as a business actor Natalia believes that consumers $\mathrm{Y}$ generation now uses fashion products as if they are no longer to meet the main needs, even consumers now tend to use different fashion products every day and at certain moments. Another reason generation $Y$ consumers use online media in purchasing fashion products is that the products purchased will be cheaper than the prices offered at offline stores. This is because generation $Y$ consumers with their stalking capabilities will conduct reviews and comparisons from one online store to another. The promos offered from the marketplace or from business people make generation $\mathrm{Y}$ consumers increasingly fond of shopping.

Promos can be obtained from promos at certain moments or holidays, promos in payment if using OVO, GoPay, Shopee pay then consumers get a discount or cash-back in the form of points that can be cashed in to buy fashion products again as well as cheap price promos when buying fashion products in quantities of more than one item. The existence of free shipping promos is also the influence of the growing interest in shopping from consumers. Notification promos obtained from consumers of marketplace users such as Shopee will make generation $Y$ consumers curious to open and buy it. Moreover, generation 
$Y$ consumers who already have their own income but are not married yet, so that the income received can be used to fulfill the desire to buy these fashion products.

According to the results of research conducted by Windayanti and Supriyadi (2019) that consumptive behavior is an action taken by an individual to buy goods or services that are excessive and without rational consideration, for the sake of physical satisfaction and encouragement to satisfy desires. The emergence of consumptive behavior is inseparable from the influencing factors such as conformity and body image. Changes in people's consumption patterns appear in the attitude of consumerism and make consumption as part of a lifestyle by paying attention to prestige and imaging and are inseparable from the changes that occur due to the industrial revolution era 4.0 that have an impact on product sales by utilizing technology (Subawa and Widhiasthini, 2018: 131).

Generation $Y$ consumers are follower consumers who use or buy a product purchased because of the influence of trends due to the influence of advertising. Follower consumers are also caused by environmental influences because not a few environments or where they are located will change lifestyle and needs. Generation $Y$ consumers easily express themselves through the social media they have. The more immersed in new and unique experiences, the more generation $\mathrm{Y}$ feels successful, let alone sharing exciting moments on social media (Mix MarComm, 2018: 40). The presence of social media allows generation $Y$ to post their consumption activities on social media. The aim is that the social media accounts owned are busy to show their existence, so that social media forces generation $Y$ to keep updating status for the sake of existence.

The use of online media in technological advancements is a reason for $Y$ generation consumers to buy a fashion product because the fashion products offered are more up-todate compared to offline stores. According to the results of the journal Subawa and Widhiasthini (2018: 138), entitled Transformation of Consumer Behavior in the Industrial Revolution Era 4.0 that several factors that caused the transformation of consumer behavior in the industrial revolution era 4.0, including follower culture, which has the meaning as a form of behavior of most people or communities in their environment which is done together.

The interesting thing in the results of the interview is the reason for using online media in purchasing fashion products, namely the practicality obtained from consumers when purchasing fashion products. Consumers do not need to go far and spend their time going to an offline store to buy fashion products. These technological and digital advancements provide many conveniences for consumers. Consumers just sit back and do a few clicks to place an order and purchase these fashion products. Desired fashion products will be sent via courier delivery services such as JNE, JNT, post, Gojek etc. Payment can also be made by transfer via mobile banking or using digital payments such as Gopay, OVO, ShopeePay etc. Only with the touch of a finger through a cellphone, laptod or other gadget the desired fashion product will soon be obtained by the consumer. A statement from Mr. I Made Sindhu Yoga that the era has provided technological facilities that provide convenience that $Y$ generation consumers will inevitably become practical.

\section{CONCLUSION AND SUGGESTIONS}

Based on the discussion in the previous chapter, the conclusion of this research is the presence of a technology that has developed in the industrial revolution 4.0 influences consumer behavior. Consumers who change their behavior are consumers who witness live birth, growth, and development of technology. These consumers are consumers who have existed in 1992-1994 range. These consumers are commonly known as $Y$ generation or millennial consumers. Generation $Y$ consumers trust individual testimonial content rather than one-way information. They no longer trust certain advertisements, but instead they will first find out reviews or testimonials conducted by other people from the internet. The characteristics of this $Y$ generation will influence consumer behavior with the advancement of this technology. One of the characteristics of Generation $Y$ is that it is more consumptive. When compared with the previous generation $Y$ will be more consumptive in purchasing fashion products because they are psychologically they will buy fashion products for lifestyle 
reasons. Purchasing fashion products through online media will be more economical in terms of price because of the promos offered by businesses. These promos attract $Y$ generation consumers to keep shopping. One of the changes in lifestyle (life style) is one of them due to environmental influences and they tend to be followers. Generation $Y$ consumers are follower consumers who use or buy a product purchased because of the influence of trends due to the influence of advertising. Follower consumers are also caused by environmental influences because not a few environments or where they are located will change lifestyle and needs. The use of online media in technological advancements is a reason for generation $Y$ consumers to buy a fashion product because the fashion products offered are more up-to-date compared to offline stores. The ease felt in purchasing fashion products such as distribution systems and payment systems that can be made all the way by using gadgets. The recent years has provided technological facilities that provide convenience that generation $\mathrm{Y}$ consumers will get, so that inevitably it will become practical.

The results of this study could suggest that future research related to the latest phenomenon is needed. Another suggestion for is to expand research subjects with different backgrounds but still pay attention to the accuracy of selecting subjects according to more specific characteristics. Limitations in this study should be overcome in future studies.

\section{REFERENCES}

1. Abdi, Lulus Prasetyo, \& Supriono. 2019. Implementasi Strategi Pemasaran Dalam Meningkatkan Daya Saing Produk Elektronik (Studi Kasus di PT. Electrolux Surabaya). Jurnal Administrasi Bisnis, 67(1), 62-71.

2. Asra, Mawat Daini, \& Suyanto, Achmad Manshur Ali. 2019. Analisis Faktor-Faktor yang Mempengaruhi Perilaku Konsumen dalam Keputusan Pembelian Telepon Selular Samsung Berbasis Android di Indonesia. E-Proceeding of Management, 6(1), 89-98.

3. Damaya. 2018. Super Student Preneur. Jakarta, Indonesia: Penerbit Laksana.

4. Kartajaya, Hermawan. 2017. Citizen 4.0 Menjejakkan Prinsip-Prinsip Pemasaran Humanis di Era Digital. Jakarta, Indonesia: PT. Gramedia Pustaka Utama.

5. Mahardika, Wayan Budi, 2019. Strategi Pemasaran Produk Makanan Catering Melalui Media Sosial Instagram. Jurnal Manajemen and Bisnis. 16(1), 13-27.

6. Mix Marcomm. 2018. Millenials. Jakarta, Indonesia: Fantasious x Loveable.

7. Oktafikasari, Eva. 2017. Konformitas Hedonis and Literasi Ekonomi Terhadap Perilaku Konsumtif Melalui Gaya Hidup Konsumtif. Economic Education Analysis Journal, 6 (3).

8. Schiffman, 2018. Perilaku Konsumen Edisi Ketujuh. Jakarta, Indonesia: PT. Indeks.

9. Sembiring, 2019. The Effect Of Viral Marketing And Customer Trust On Online Shop Purchase Decisions Based On Application In Faculty Of Economic And Business Universitas Sumatera Utara. The International Conference University Of Asahan 2019.

10. Simaremare, Sri Indah, and Mujiasih, Endah. 2018. Hubungan Antara Customer Value dengan Impulse Buying Produk Fashion Pada Mahasiswi Angkatan 2017 Psikologi Universitas Dipenogoro. Jurnal Empati, 7(4):162-167.

11. Soeaidy, Mohammad Soleh, Taufiq, Adhitya Rahmat, \& Mandasari, Andina Eka. 2018. Stimuli Pada Generasi Millennial Untuk Mau Membayar Harga Premium Fasion Muslim Melalui Status Merek and Preferensi Merek. Jurnal Ekonomi Manajemen, 4(1):29-37.

12. Subawa, Nyoman Sri. Transformasi Perilaku Konsumen Era Revolusi Industri 4.0. 2018. Conference on Management and Behavioral Studies. 131-139.

13. Sudarwinarti, V.Y Sri. 2019. Pentingnya Berfikir Kritis Generasi Milenial di Era Industri 4.0. Jurnal ADB'S Secretary, 8(1): 1-89.

14. Sugiyono. 2014. Metode Penelitian Kuantitatif, Kualitatif, and R\&D. Bandung, Indonesia.

15. Sugiyono. 2015. Metode Penelitian Kuantitatif, Kualitatif, and R\&D. Bandung, Indonesia.

16. Suryadi, Bambang. 2015. Generasi Y: Karakteristik, Masalah and Peran Konselor. Seminar and Workshop Internasional Malindo 4 di Bali.

17. Windayanti, Ni Luh Ayu Putri, and Supriyadi. 2019. Hubungan Antara Citra Tubuh and Konformitas Terhadap Perilaku Konsumtif Pada Remaja Putri di Universitas Udayana. Jurnal Psikologi Udayana, 6(2):1101-1113. 